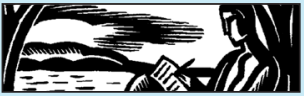

\title{
Funerary Artefacts, Cemetery Souvenirs and Final Resting Places
}

\author{
Catherine Bell
}

Australian Catholic University

\section{ABSTRACT}

This photo essay discusses artworks that explore the commemorative dimensions of death through socially-engaged artistic processes, and the use of Oasis ${ }^{\circledR}$ floral foam-an ephemeral material that is integral to making flower arrangements that venerate the cycles of life and the celebratory milestones between birth and death. It examines the material's uncanny corporeal associations when it is formed into vessels, and the ways in which the foam may be seen to transform meaning into materiality. It reflects on how the exhibition of cremated remains of Roman Londoners with associated funerary vessels, titled Roman Dead, at the Museum of London Docklands, informed a series of miniature foam gravestones adorned with custom-designed vessels created on site at East London's Tower Hamlets Cemetery Park, and a series of art workshops in hospice settings with palliative care staff, which were designed to promote meaningful reflection and healthy discussion about death and dying.

Keywords: urn, final resting place, floral foam

The graveyard is a place of 'impossible' communication; there is no dialogue with the dead, so we have to learn another use for language. ${ }^{1}$

This photo essay discusses a series of artworks entitled 'Crematorium Vessels' (2012-2013), created during a year-long residency at Caritas Christi Hospice in Melbourne, Australia, and the development of the project with associated workshops during a residency at The Centre for the Study of Substructured Loss Applied Grief and Bereavement Research in London in $2018 .^{2}$ 
The residencies in Melbourne and London explored the commemorative dimensions of death through socially engaged artistic processes and the use of ephemeral materials. In both of these projects Oasis ${ }^{\circledR}$ floral foam was used as an art medium because it is integral to making flower arrangements that venerate the cycles of life and the celebratory milestones between birth and death. This essay examines the uncanny correspondences between the floral foam, its materiality and function, and the sites of death and dying. These themes were explored in a new body of artwork that aimed to contribute to a cultural understanding of death. A communal art workshop, using the concept of facing death creatively, was also designed to facilitate new methods of learning 'another use for language' by promoting creative and reflective approaches, to generate greater insight into one's final resting place.

At Caritas Christi Hospice, floral foam (an often-discarded material) was collected from palliative-care wards after the floral arrangements had died, and was then repurposed as a sculptural material (Fig. 1). The floral foam was salvaged from patients' bedrooms and recycled into hand-crafted urns that were placed throughout the hospice. Poised as if to receive the ashes of the deceased, the containers bound together the

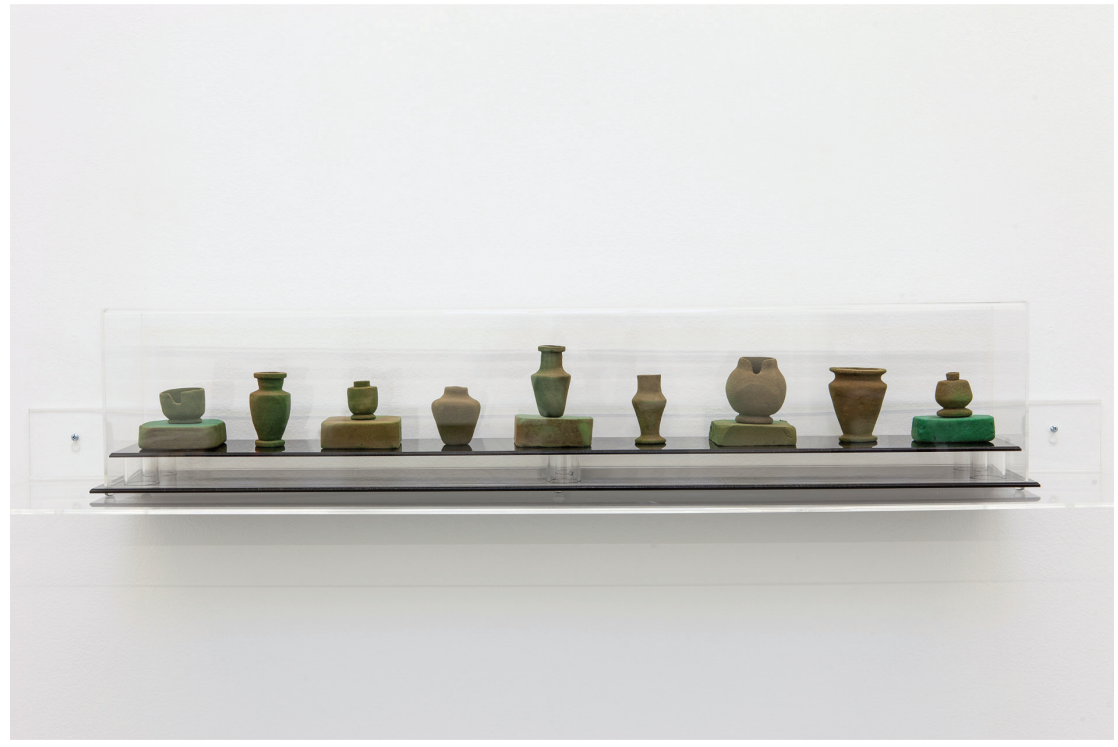

Fig. 1 Catherine Bell, Crematorium Vessels, 2012-2013.

Hand-carved, recycled floral foam. Image courtesy the artist and Sutton Gallery, Melbourne. Photo: Andrew Curtis. 
living and the dead. Reclaiming the floral foam from the site imbued it with the history of the place and the patients who had contact with it. Sculpting it into commemorative relics marked the transformation of meaning into materiality: giving voice to the departed and the act of bearing witness. Over the year-long residency the floating dust, made up of human skin cells of bodies past and present inhabiting the hospice, collected inside and on the surface of the urns, creating a rust-coloured patina. This discolouration serendipitously gives the vibrant green containers the appearance of age evocative of bronze antiquities (Fig. 2).

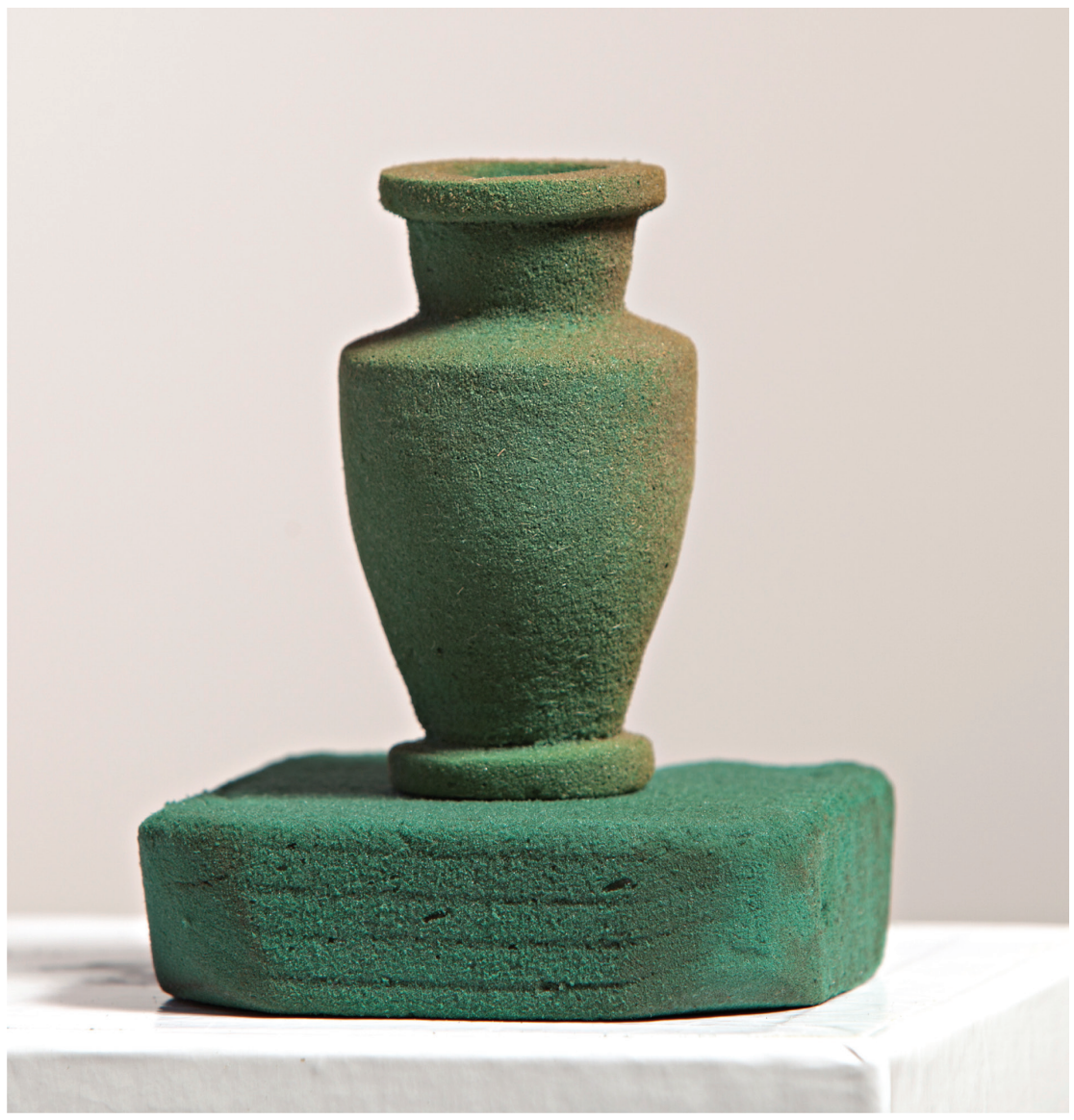

Fig. 2 Catherine Bell, Crematorium Vessels, detail, 2012-2013.

Hand-carved, recycled floral foam. Image courtesy the artist and Sutton Gallery, Melbourne. Photo: Andrew Curtis. 
Unlike ancient artefacts displayed in regulated museum environments that control light, temperature, and humidity, the urns displayed in the hospice setting are exposed to these elements, which accelerate material decay. The surface mutations are a physical sign that these ephemeral sculptures are decomposing over time. This process heightens the material's relationship to the corporeal, as the patina is suggestive of human ageing. The vulnerable and ambiguous materiality of these forms invokes archaeological relics and aligns them with the absent dead and their material culture. This association resonates with physician and author Sir Thomas Browne's writing on ancient death practices, in particular Urn Burial (1658), where he discusses how the interment of burial urns align both past and present civilisations by connecting the living with the dead. He describes these objects as 'sad and sepulchral pitchers, which have no joyful voices, silently expressing old mortality, the ruins of forgotten times, and can only speak with life'. ${ }^{3}$ This statement emphasises the role of material culture in relation to death and memory-specifically how artefacts bridge spatio-temporal chasms, making past civilisations accessible, uniting the living with their ancient forebears.

As I would discover during the next phase of the project, in England's oldest cemeteries age is suggested by graves covered in a layer of spongy, green moss reminiscent of the damp floral foam. During the residency in London, the graveyard, like the hospice setting, would become a studio in which to research and develop a visual language that would facilitate communication concerning death. At Tower Hamlets Park Cemetery in the East End of London, floral foam was revealed as a precarious material with uncanny corporeal associations; over time becoming a grave for decaying flowers, it is often seen scattered around cemeteries after the floral arrangements adorning the burial grounds have decomposed. The lingering floral foam, like the anonymous gravestones, becomes a melancholy reminder of the finite history embodied in these decaying structures. ${ }^{4}$

Two types of floral foam were used during the residency in London, reinforcing contrasting themes of decay and preservation, fragility and resilience, natural and artificial, ephemerality and permanence. A browncoloured, biodegradable floral foam was selected for communal art workshops with the public (Fig. 3); a green variety similar to the craft material salvaged and recycled from the hospice settings in Melbourne was used to make a series of decorative objects (Fig. 4) inspired by the hand-carved marble monuments and funerary vessels that adorn Victorian graves (Figs. 5 and 7). Pristine floral foam shaped into spheres and bricks was also sourced, so that larger sculptures could be created without the structural integrity of the material being compromised by using the more brittle and crumbling recycled floral foam (Fig. 6). 


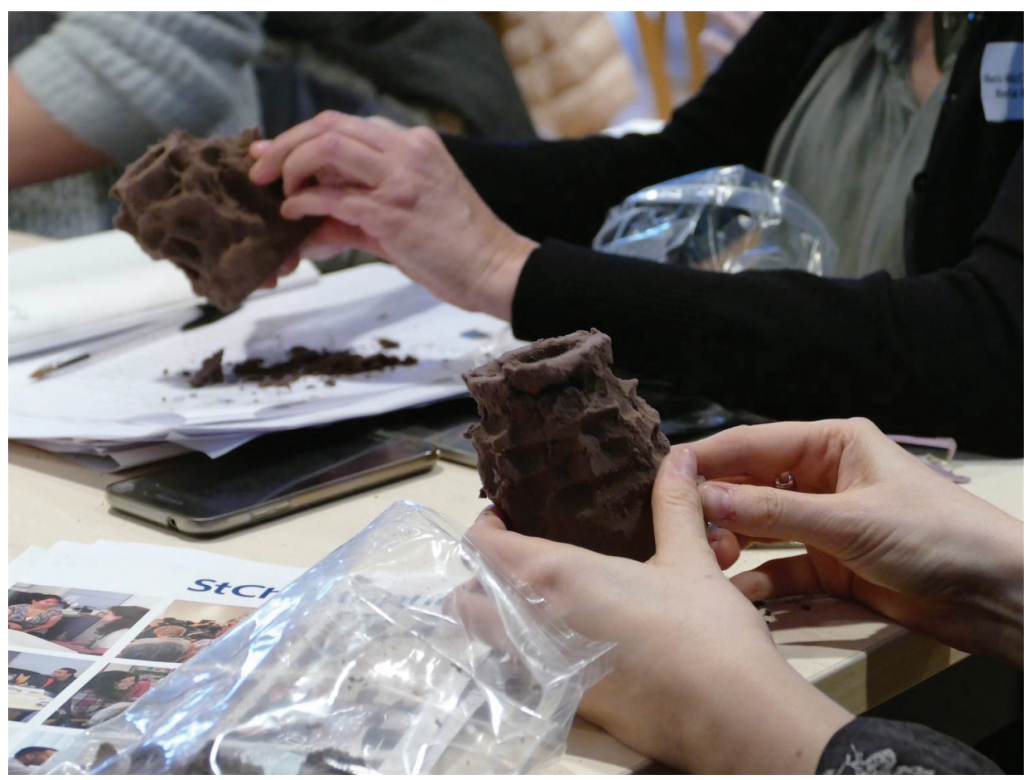

Fig. 3 Catherine Bell, Final Resting Place, 2018.

Communal workshop conducted at St Christopher's Hospice London. Photo: Katie Baulkwill.

The sculptures produced at Tower Hamlets Cemetery were made in response to vessels and artefacts that punctuate the graves there (Fig. 7), and which also resonated with artefacts included in an exhibition entitled Roman Dead, which was on display at the Museum of London Docklands during 2018. ${ }^{5}$ In this exhibition a large ceramic vase stood out, not because its form was distinctive, but because its function was unusual. It had once been buried underground with its neck left sticking out as a grave marker that also served as a portal to the deceased. On special occasions, mourners could visit the grave and pour liquid offerings like wine or perfumed oils into the opening, creating a metaphorical passage connecting the living with the dead. ${ }^{6}$ This ceremonial gesture anthropomorphises the opening of the vase and transforms the hole into a wound that is periodically tended but never healed. This action demonstrates how the vase facilitates 'communication' with the dead through rituals of care and devotion.

Today, the tradition of using a vase as a grave marker continues, but its altered function indicates the changes that have occurred in how 


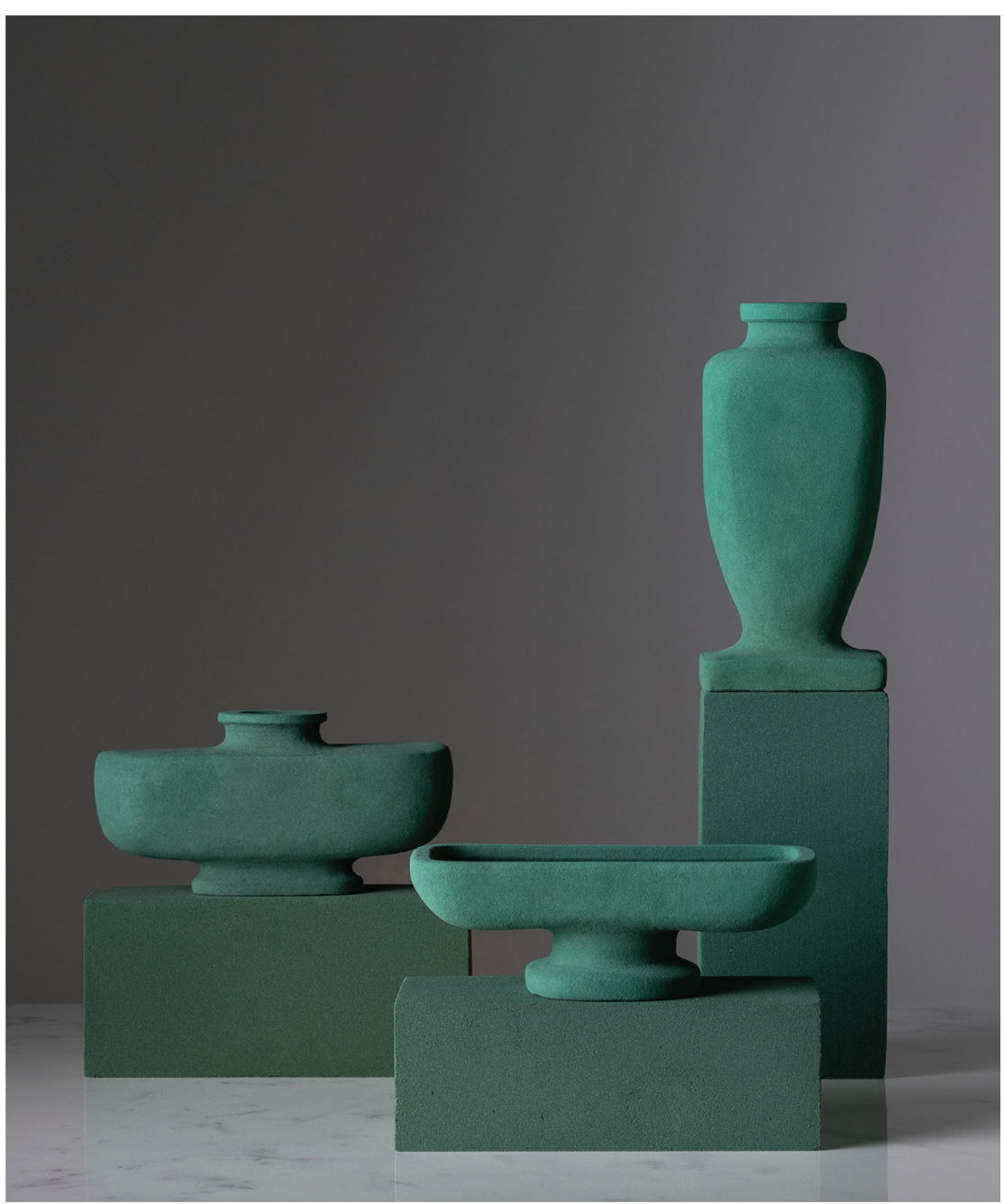

Fig. 4 Catherine Bell, Cemetery Vessels Trilogy, 2018.

Hand-carved floral foam. Image courtesy the artist and Sutton Gallery, Melbourne. Photo: Andrew Curtis.

we relate to the dead. In Victorian cemeteries the vase continues to be used as a site for mourners to connect with the deceased; however, when the vessel moves above ground and is positioned on top of the grave, the purpose of the opening shifts. It is no longer a visceral passageway linking the buried with the world above, but a static container 


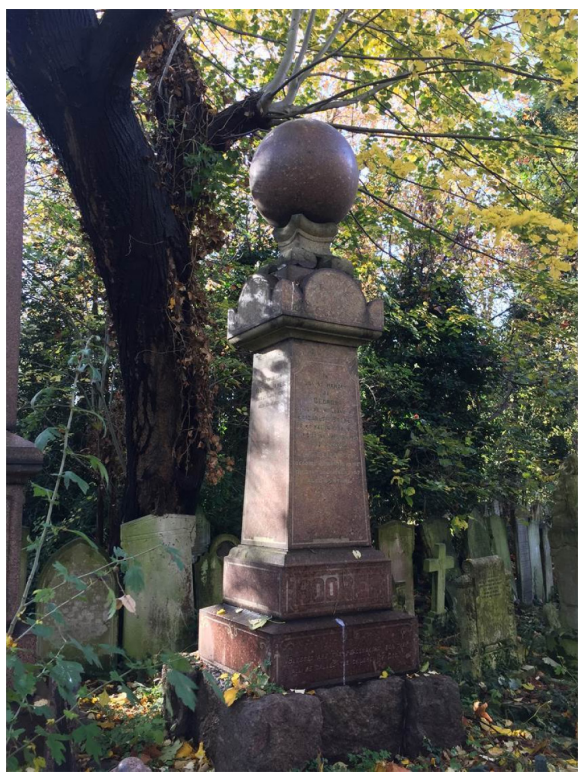

Fig. 5 Grave Monument, Tower Hamlets Cemetery Park, London, 2018. Photo: Catherine Bell.

holding floral tributes. Repurposing the vessel seals the passage and removes the physical conduit into the burial place, shifting focus away from its inhabitant and drawing attention to the aesthetic appeal of the grave.

In contrast, the Roman Dead exhibition revealed how containers were once used to maintain an intimate relationship with the deceased by being buried with the body so that their contents could be used in the afterlife. ${ }^{7}$ The Roman Dead also displayed exhumed, cremated remains of Roman Londoners once contained in ceramic and glass urns. The desiccated remnants had been emptied for public view and were exhibited alongside their respective containers; excavated human skeletons were presented as they were discovered, surrounded by numerous tiny ceramic pots and glass vials that held unguents or food (Fig. 8). These displays demonstrated how ancient death rituals symbolically related the deceased to the accompanying consecrated objects. While cremation reduces the corpse to ash, allowing it to be contained inside the burial urn, inhumation keeps the skeleton intact and allows a constellation of vessels to be placed around it, intensifying their ceremonial meaning and the nexus between the body, the vases and death. 


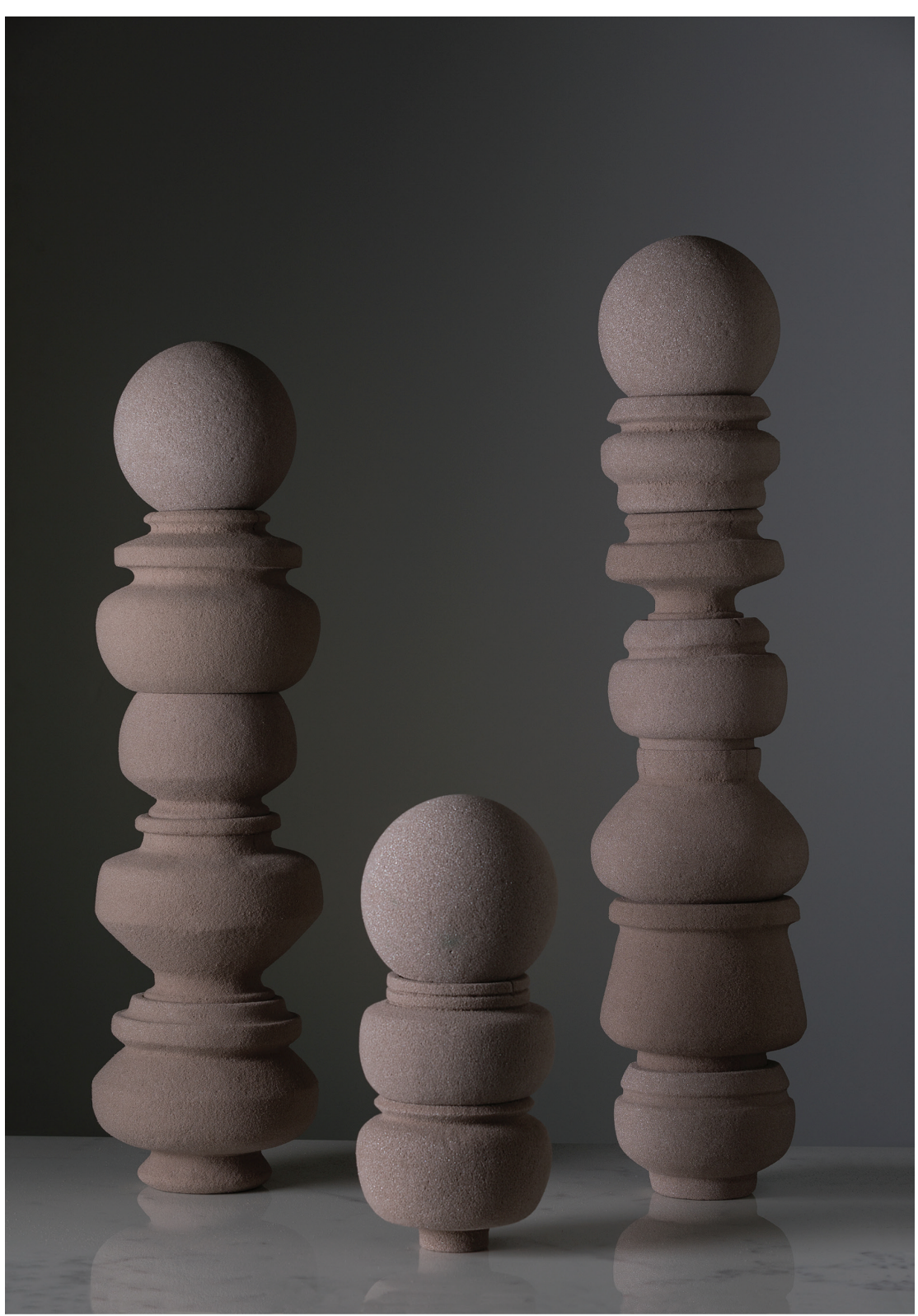

Fig. 6 Catherine Bell, Family Group, 2018.

Hand-carved floral foam. Image courtesy the artist and Sutton Gallery, Melbourne. 


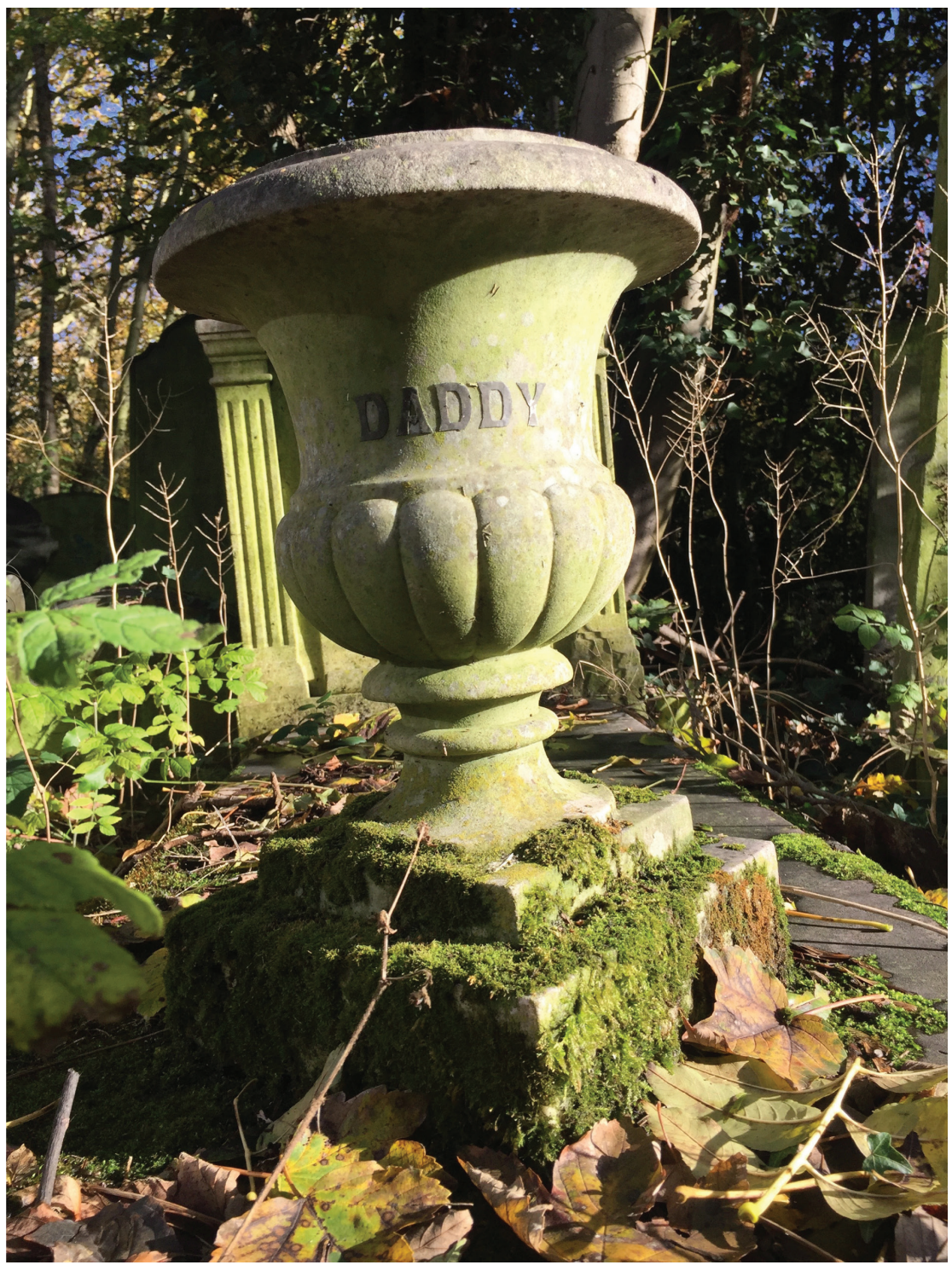

Fig. 7 Grave Vessel. Tower Hamlets Cemetery Park, London, 2018.

Photo: Catherine Bell. 


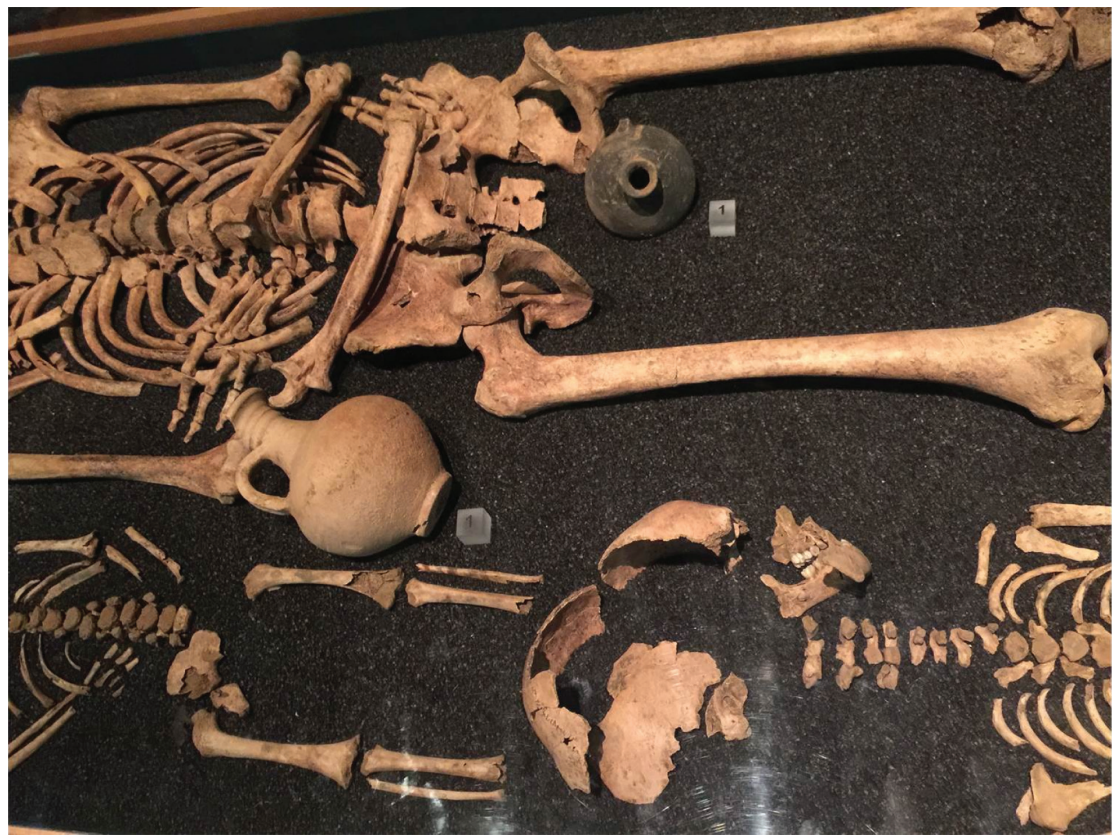

Fig. 8 Roman Dead, exhibition detail, 2018.

Museum of London Docklands. Photo: Catherine Bell.

Also on display in the Roman Dead exhibition were ornately decorated lead coffins that preserved the bodies of venerable figures. Lead-a toxic material that endures long after the body decomposes-functions to preserve the body for as long as possible, just as floral foam is used to preserve the life of flowers. Both materials introduce a range of non-degradable elements, at odds with the contemplation of natural decay. The green floral foam used to make the new series of decorative funerary artefacts and cemetery souvenirs is toxic, like many of the materials associated with human burial: chemicals used to embalm the bodies, varnishes, sealers, preservatives, metal handles and ornaments used on wooden coffins, and lead used to line and seal the inside of coffins. The non-degradable nature of the medium raises further questions about the harmful environmental effects associated with human burial and the growing interest in ecological alternatives to body disposal such as natural burial. ${ }^{8}$ Recycling the floral foam that accumulates in hospice and hospital settings and repurposing it into funerary objects prevents it from becoming landfill. In contrast, a non-toxic, biodegradable variety of floral foam was selected for use in workshops as a means of facilitating discussion about 
how death may be communicated and understood through a response to the medium's natural decay when the dust remains are scattered in the environment.

The series of miniature floral foam gravestones, adorned with customdesigned, hollowed out vases created on site at Tower Hamlets Cemetery, were inspired by the marble and stone vases positioned there to receive floral offerings to the deceased (Fig. 9). On a reduced scale, these vibrant green sculptures mimic the moss-covered graves and become portable souvenirs of the originals. When removed from the site, they may signify our impending death and act as a reminder of the body's metaphoric associations with material objects. Modelling them on site initiated impromptu conversations with the public about how they view death and their imagined final resting place. We also discussed the disappearing cemetery surrounding them and whether the graves should be preserved, remain unkempt and left to deteriorate, or removed completely and the site redeveloped.

While local people seem indifferent to Tower Hamlets Cemetery's forgotten and decaying history, in contrast there is considerable civic interest surrounding the unearthing of ancient Roman burial grounds and the

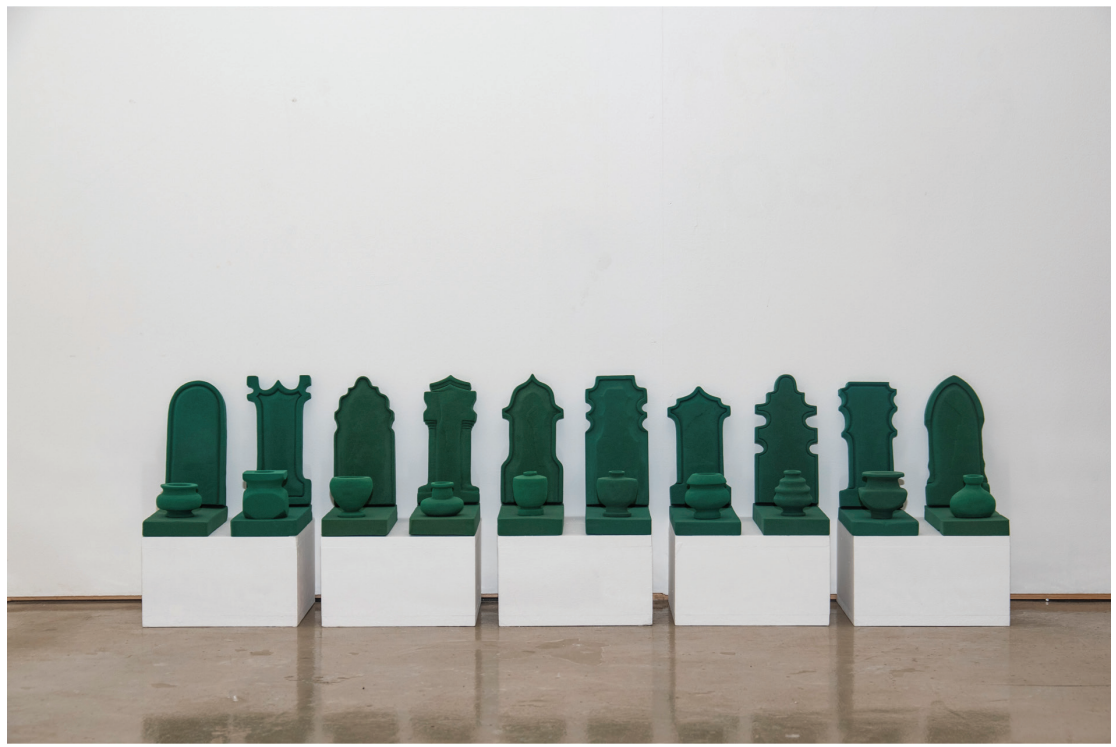

Fig. 9 Catherine Bell, Cemetery Souvenirs, 2018.

Hand-carved floral foam. Image courtesy the artist and Sutton Gallery, Melbourne. 
discovery of archaic human remains in the metropolis. The popularity of the Roman Dead exhibition demonstrates the public's enduring fascination with how early civilisations commemorated their dead. The history of the cemetery movement in Britain often made reference to classical burial, popularised in Victorian times, in the style and design of graveyard monuments and ornamentation inspired by Egyptian, Roman and Greek architecture. The aesthetic status commanded by classical burials is reflected in the following statement: 'by making reference to a glorious past, the erectors of these memorials could be said to frame themselves as the heirs of an illustrious, imperial tradition thus gaining prestige and legitimisation in the present'. ${ }^{9}$

Visiting this exhibition would influence the design of art workshops that I led at St Christopher's Hospice, as part of their Facing Death Creatively symposium in 2018. At these workshops, conference delegates sculpted biodegradable floral foam to create a small urn, which would become a 'portrait' of the maker and a catalyst for imagining their final resting place. Working with this medium communally to produce fragile urns provided an opportunity to promote healthy and meaningful reflection on mortality. The dust that accumulated during the creation of the little urns was collected in ziplocked freezer bags, which participants took away to use as the basis for opening discussion with loved ones about their final resting place. Participants were also invited to scatter the biodegradable dust in the location where they could imagine themselves being buried, or their ashes dispersed, and to email me a photo of the site. The sculpted forms created during the workshops were relinquished and became part of a growing archive of individually hand-crafted pots, which represent the community that created them at a particular place and time (Fig. 10).

Assembled together, they also represent their makers and symbolise the group that participated in the communal creativity. These brown pots bear an uncanny resemblance to the ceramic urns that the Romans buried with the deceased. Their creation mimics archaeological excavations that remove compacted dirt to reveal the precious artefacts beneath. During the workshops, unplanned objects emerged organically as the floral foam block was methodically rubbed away to reveal the hidden forms. This meditative process encouraged contemplation on impermanence, and the participants were asked to reflect on where they envisage their cremated remains being scattered or their body buried. This proved discomforting for some participants, who thought their final resting place should be a decision made by those they leave behind. Others have a definite place in mind and show me an image on their phone of a beach where they surf, a park they like to visit, or a landscape that has ancestral significance. 


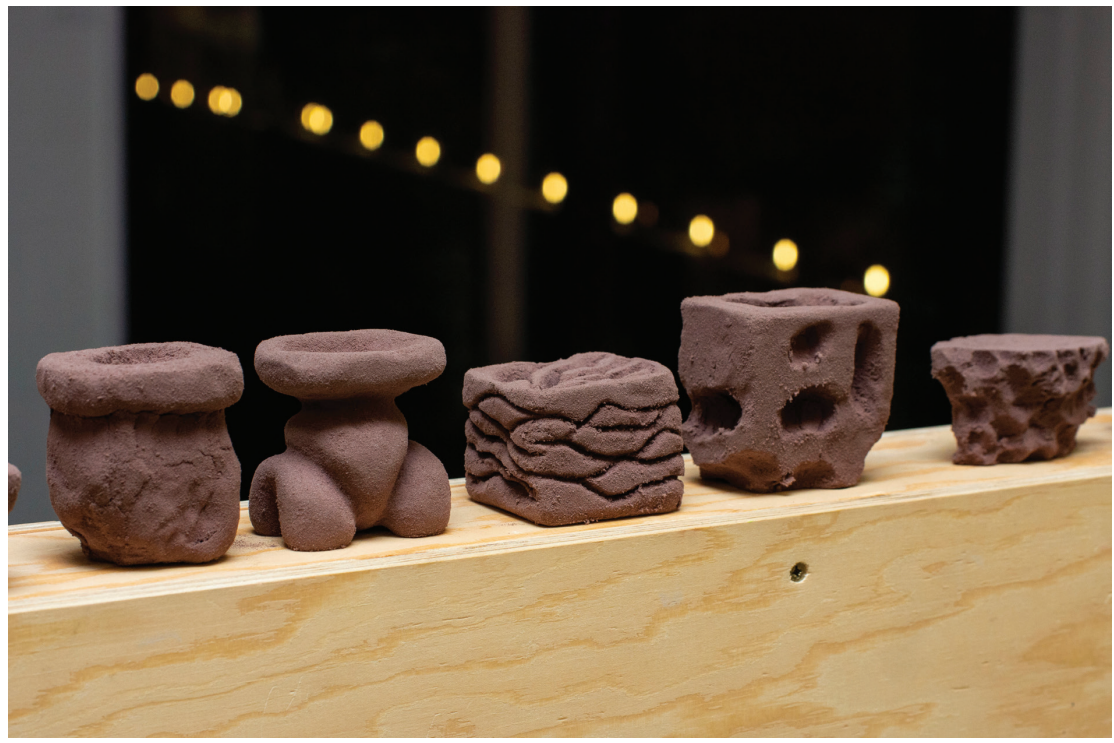

Fig. 10 Catherine Bell, Final Resting Place Vessels, 2018.

Bow Arts, Royal Albert Wharf, London. Photo: Catherine Bell.

Identifying where their final resting place is and discussing why it is important helps others in the group to consider a meaningful place in their lives. This focuses the conversation about the final resting place and its association with life. Articulating the place in the workshop is a rehearsal for sharing thoughts about that final resting place, and why it is meaningful, with their loved ones. Taking the dust away becomes a prompt to continue the conversation about death and encourages visiting the place that has significant meaning to the participant. Going there to scatter the dust, document the location and send me the image is a process that connects the lived experience to the place and ultimately connects the memory of the participant to an emotional place of remembering.

This project, which began as socially engaged artistic practice in a hospice in Australia, travelled to London where ancient Roman burial rituals and neglected Victorian cemeteries informed the development of new ways of talking about the selection of a final resting place. The creative process of reduction and the entropic nature of the medium allowed a precarious and often overlooked material with corporeal associations to be transformed from a solid brick to a hollow container, to a pile of dust. Throughout each of these stages, and regardless of the type of floral foam that was used, the material outcome was preserved. The creation of the 
artworks was relocated from the hospice setting to the graveyard, and the location became a testing ground for interacting with the public and using art to facilitate discussion about death.

Shipping this body of work, created in London, back to Australia would become a symbolic journey that speaks to the artwork's final resting place. I contemplated burying the communally made urns made from the biodegradable floral foam at a London building site and gifting the other works to funeral parlours to decorate their window displays. This seemed easier than trying to transport them back to Australia and explaining to customs what the ephemeral sculptures were, and potentially having to convince them there was no organic material in the floral foam sculptures. The floral foam dust collected in zip locked freezer bags would also potentially be cause for concern when the boxes were x-rayed. Thankfully nothing was questioned by customs and the sculptures that I presumed would be pulverised to dust (due to the fragility of the material, the delicate construction of the objects and the rigours of transporting the work over such a vast distance) arrived intact.

The safe delivery of this body of work has spurred on my continuation of the communal workshops with different community groups, in order to expand the growing archive of hand-crafted urns and images of final resting places. Just as the Roman Dead exhibition influenced my view of death, I want these artworks and communal workshops to help others to reflect on their mortality and the strong aesthetic and spiritual connection that these communally created containers have to the archaic relics of ancient civilizations.

Returning to the essay's epigraph, this project has facilitated new ways of learning 'another use for language' through eliciting conversations with the public about death in the graveyard setting and facilitating communal creativity that generates discussion about the difficult subject of selecting a final resting place. At the core of both these projects is framing death as a creative and productive set of relations, where the context for understanding death is embedded in visual language and socially engaged approaches. This methodology positions death as a provocation for creative expression, reflection, and interpersonal exchange. It allows the participants to hone their awareness of the centrality of mortality in life and examines death within the social and spatial contexts in which it is encountered.

\section{ACKNOWLEDGEMENTS}

The author would like to thank the editors for their insightful feedback and helpful references, which have situated the artworks with relevant scholarship and offered trajectories for future research. 


\section{WORKS CITED}

Browne, Thomas. In: Edward H. Marshall and Alexander Greenhill (eds.), Sir Thomas Browne's Hydriotaphia and The Garden of Cyrus. London: Macmillan, 1911.

Clayden, Andy, Jenny Hockey and Mark Powell. 'Natural Burial: The De-materialising of Death?' In: Jenny Hockey, et al. (eds.), The Matter of Death: Space, Place and Materiality. London: Palgrave Macmillan, 2010.

Rumble, Hannah, John Troyer, Tony Walter and Kate Woodthorpe. 'Disposal or Dispersal? Environmentalism and Final Treatment of the British Dead.' Mortality 19:3 (2014) 243-260.

Tarlow, Sarah. 'Landscapes of Memory: The Nineteenth Century Garden Cemetery.' European Journal of Archaeology 3:2 (2000).

Townsend, Chris. Art and Death. London: I.B. Tauris, 2008.

Walker, Susan. Memorials to the Roman Dead. London: British Museum Publications, 1985.

\section{WEBSITE}

https://www.museumoflondon.org.uk/discover/unearthing-roman-dead-docklands

\section{ABOUT THE AUTHOR}

Associate Professor Catherine Bell is a multi-disciplinary artist and academic teaching visual art in the Faculty of Education and Arts, Australian Catholic University. Her art practice explores the role of the artist in the archive and healthcare setting, art on the margins, socially-engaged and relational approaches to art making, feminist and care ethics in collaborative practice and challenging taboos surrounding death and dying. Recent artist residencies in the oncology ward at St Vincent's Hospital and Caritas Christi Hospice in Melbourne involved implementing communal creativity with patients and staff to promote healthy and meaningful discussion on death and the dying. She is represented by Sutton Gallery, Melbourne. https://suttongallery.com.au/artists/catherine-bell/. E-mail: catherine.bell@acu.edu.au.

\section{NOTES}

1 Townsend, Chris. Art and Death. London: I.B. Tauris, 2008 (127).

2 The residency at The Centre for the Study of Substructured Loss Applied Grief and Bereavement Research was located at BOW ARTS RAW Labs - Norton Quays, Royal Albert Wharf, London E16 2QJ. The residency period was 22 OCT 2018-10 DEC 2018 and the project was funded by the Australian Government through the Australia Council, its arts funding and advisory body. The 2012-2013 residency at Caritas Christi Hospice, Melbourne, was support by St Vincent's Hospital Artist Residency Programme.

3 Browne, Thomas. Sir Thomas Browne's Hydriotaphia and The Garden of Cyrus. In: Edward H. Marshall, Alexander Greenhill (eds.). London: Macmillan, 1911 (4). 
4 Thomas Browne in Urn Burial also ruminates on the transitory duration of monuments and speculates on the grave or final resting place as a temporal site: 'But who knows the fate of his bones, or how often he is to be buried.' Idem (3).

5 Link to information about the Roman Dead exhibition can be found at: https://www.museumoflondon.org.uk/discover/unearthing-roman-dead-docklands.

6 Walker, Susan. Memorials to the Roman Dead. London: British Museum Publications, 1985 (10).

7 Idem (11).

8 Rumble, Hannah, John Troyer, Tony Walter and Kate Woodthrope. 'Disposal or Dispersal? Environmentalism and Final Treatment of the British Dead.' Mortality 19:3 (2014) (243-260); Clayden, Andy, Jenny Hockey and Mark Powell. 'Natural Burial: The De-materialising of Death?' In: Jenny Hockey, et al. (eds.), The Matter of Death: Space, Place and Materiality. London: Palgrave Macmillan, 2010 (148-164).

9 Tarlow, Sarah. 'Landscapes of Memory: The Nineteenth Century Garden Cemetery.' European Journal of Archaeology 3:2 (2000) (229). 